\title{
DIARRHEA SYNDROME CAUSED BY CAMPYLOBACTER JEJUNI IN
}

\section{CALVES}

\author{
HALA, M. ISMAIL ${ }^{1}$ AND SHEREEN S. MOUSTAFA ${ }^{2}$ \\ ${ }^{1}$ Pathology Unit, (Animal Health Research Institute, Mansoura Lab), Agriculture Research Center (ARC). \\ ${ }^{2}$ Bacteriology Unit, (Animal Health Research Institute, Mansoura Lab), Agriculture Research Center (ARC).
}

Received: 20 April 2021; Accepted: 30 May 2021

\begin{abstract}
Campylobacter jejuni (C.jejuni) is the leading bacterial cause of food born diarrheal illness and enterocolitis worldwide in human and young animals. A total of 140 samples (100 fecal samples of calves and 40 raw milk samples of cow) were collected from Dakahlia governorate dairy farms for isolation and identification of C.jejuni by using cultural, biochemical, molecular methods and detection of the virulent $c a d F$ gene using PCR. Moreover, the isolated C.jejuni subjected for antimicrobial susceptibility test. Then, we develop an experimental infection of rabbits by inoculation with $1 \times 10^{9}$ colony-forming units (cfu) of completely identified C.jejuni. Rabbits divided into 3 groups: infected untreated (G1), infected treated with enrofloxacine (G2), control (G3) to study pathogenesis, fecal inflammatory response, histopthology, immunohistochemistry and ultrastructural changes post inoculation in the three groups. Results revealed that, from 140 fecal and raw milk samples only 41 isolates were bacteriologically and biochemically identified as Campylobacter spp. Seven isolated strains were positively amplified for mapA gene specific to $C$.jejuni and carried the $c a d \mathrm{~F}$ virulence gene. C.jejuni isolates were resistant to amoxicillin and ampicillin and highly susceptible to norfloxacine and erythromycin. After oral infection with $C$. jejuni $90 \%$ of rabbits developed diarrhea with highly fecal inflammatory responses in G1, but mild in G2 (treated) and negative in G3 (control). Pronounced histopathologic changes were investigated in G1 during the acute phase (days 1 to 3 ) restricted on distal small intestine and colon including massive destruction of villi and loss of intestinal glands. The submucosa and muscularis mucosa showed the presence of edema with congested blood vessels, while hemorrhage was seen in the muscularis propria layer. The changes were mild and involved only the villi in treated group (G2), while abscent in control (G3). These results were confirmed by immunostaining, suggesting that $C$.jejuni is capable of invading deep intestinal tissues down to the submucosal layer in G1 while in G2 infection, the reaction was confined mainly to the villi, and was greatly reduced in the submucosa. Electron microscope showed all stages of invasion and associating damages from postinfection, colonizationa and villus damage. Thereby, the implementation of hyagenic practices during milking and proper handling of milk during calves feeding with regular monitoring of antibiogram profile are very crucial in preventing C.jejuni infection, colonization and intestinal damage and subsequently economic loss in dairy farm.
\end{abstract}

Keywords: C.jejuni; Calves; Diarrhea; PCR; cadF gene; Intestine; pathology.

Corresponding author: HALA, M. ISMAIL

E-mail address: ibrahimsabry.gravena@gmail.com

Present address: Pathology Unit, (Animal Health Research Institute, Mansoura Lab), Agriculture Research Center (ARC). 


\section{INTRODUCTION}

Calf diarrhea is a multifactorial disease and a major problem in livestock production in Egypt and throughout the world (Ibrahim, 2007) which have serious financial and animal welfare implications in both dairy and beef sucker herds (Uhde et $a l ., 2008)$. It has been detected that $75 \%$ of early calf mortality in dairy herds is caused by acute diarrhea in the pre-weaning period, also still a major cause of economic loss to cattle producers worldwide (Bartels et al., 2010). The aetiology of diarrhea is complex involving management, environmental, nutritional, physiological variations and variety of pathogens (Prescott et al., 2008), but $80 \%$ of tested diarrheic calves indicated that infectious factor is still a major cause of calf diarrhea (Meir et al., 2010). The majority of diarrheic cases were identified among 0 to 4 week old calves (Wudu et al., 2008). Although E. coli and Salmonella are known to be the most common and economically important agents (Achá et al., 2004), Campylobacter spp, principally C.jejuni is among the main causes of gastroenteritis in newly born calves worldwide. Moreover, it is important human pathogens that may cause outbreaks of food-borne diseases and thus are of high public health importance (Cho, 2012). Raw milk acts as the main source for Campylobacter spp. and primarily to be contaminated by bovine feces or direct contamination of milk as a consequence of mastitis (Modi et al., 2015).

Campylobacter isolation and identification is considered the standard method for disease identification; however, it is laborious due to the complex nature of Campylobacter (Li et al., 2014). Thus, molecular techniques, such as polymerase chain reaction (PCR) and sequencing, can permit the simple, fast and exact identification of $C$. jejuni and reveals its epidemiological characteristics (Miller et al., 2010).
The disease seriousness relies upon the virulence of the strain and on the host's immune state (Younis et al., 2018). CadF is one of the reference virulence genes that encodes proteins involved in the attack and attachment of $C$. jejuni (Elmali \& Can, 2019), and this gene is a highly prevalent in C. jejuni isolates and have been proposed to play a role in enteritis and colonization in the luminal surface of the small bowel (Andrzejewska et al., 2015).

Antimicrobial susceptibility test represents one of the most important an epidemiological tool and definition of the proper treatment of infections, consequently preventing or creating strategies that minimize the dissemination of resistant bacterial strains, mainly multiresistant ones especially Campylobacter spp (Shang et al., 2016), which has a potentially serious impact on food safty in both animal and human health (Hagos et al., 2021).

Despite extensive study, little is understood about the mechanism by which $C$. jejuni causes diarrheal disease, so various small animal models have been reported to study the process of enteroinvasiveness by $C$. jejuni (Heimesaat et al., 2014). The gastroenteritis due to Campylobacter ranges from mild to severe diarrheal disease (often bloody diarrhea), other symptoms are cramping, abdominal pain and fever within 2-5 days after exposure to the organism, which typically lasting 1 week with Complications (Murray et al., 2007), which attributed to virulence factors that could play a role of colonization, adherence, and invasion of epithelial cells in the animal and human being (Wilson et al., 2010).

The aim of this study were to isolate and identify $C$. jejuni from naturally infected calves and raw milk, and to determine the antibiotic susceptibility pattern for perfect control and treatment. Moreover, using an experimental rabbit model to study histopathological, immunohistochemichal and ultrastructural changes, as well as to enable testing of new therapeutics to prevent and/or combat infection. 


\section{MATERIAL AND METHODS}

\section{Samples collection}

Atotal of 140 samples including raw milk (40) and sterile cotton rectal swabs (100) were collected from different farms exhibited severe diarrhea in newly born calves at Dakahlia Governorate in the period from December 2019 to April 2020. All samples were collected in sterilized bottles and were immediately transported to the laboratory in an insulated ice box at $4 \mathrm{C}$ within 1-2 $\mathrm{h}$ from collection and processed immediately upon arrival for isolation.

\section{Campylobacter Isolation}

Samples were examined for the presence of Campylobacter spp. using selective enrichment and isolation protocol recommended by Roberts and Greenwood (2003). One $\mathrm{ml}$. of the homogenized samples was aseptically inoculated into sterile screw capped tube, containing $9 \mathrm{ml}$ of Bolton broth (Oxoid Ltd, Basingstoke, Hampshire, England) containing 5\% laked horse blood and Bolton broth selective supplement which incubated under appropriate microaerophilic conditions in anaerobic jar by using the Gas Pack System BBL $(5 \% \mathrm{O} 2,10 \% \mathrm{CO} 2$ and $85 \% \mathrm{~N} 2)$ at $37^{\circ} \mathrm{C}$ for about 4 hours prior to increasing the temperature to $41.5^{\circ} \mathrm{C}$ for the remainder of the 48 hours of the incubation time for resuscitation. Loopful of the incubated broth was plated onto modified Charcoal Cefoperazone Deoxycholate Agar (mCCDA, Oxoid) with CCDA selective supplement and the plates were incubated for 48 hours at $41.5^{\circ} \mathrm{C}$ under appropriate microaerophilic conditions, suspected colonies were selected and isolated.

\section{Campylobacter Identification}

Presumptive colonies of Campylobacter spp. were subjected to standard biochemical tests (Foster et al., 2004), including oxidase test, catalase production test, nitrate reduction test, hydrogen sulphide production using lead acetate paper, glycine tolerance test, $\mathrm{NaCl} 3.5 \%$ tolerance test, sensitivity to Nalidixic acid and Cephalothin and Hippurate hydrolysis test. Biochemically identified $C$. jejuni colonies were stored at $-70{ }^{\circ} \mathrm{C}$ in nutrient broths with $15 \%$ glycerol until subjected to molecular PCR identification.

\section{Molecular characterization of $C_{. j}$ ejuni 4.1.DNA extraction:}

DNA extraction from samples was performed using the QIAamp DNA Mini kit (Qiagen, Germany, GmbH) with modifications from the manufacturer's recommendations.

\subsection{Polymerase chain reaction (mapA gene)}

The amplification of the mapA gene for $C$. jejuni was carried out on 10 representative isolates that were biochemically confirmed utilizing the primers listed in Table 1 . Amplification conditions were as follows: 6 minutes at $94{ }^{\circ} \mathrm{C} ; 35$ cycles of 50 seconds at $94{ }^{\circ} \mathrm{C}, 40$ seconds at $57^{\circ} \mathrm{C}$, and 50 seconds at $72{ }^{\circ} \mathrm{C}$; and a final extension of 3 minutes at $72{ }^{\circ} \mathrm{C}$. The PCR products were analysed using $1.5 \%$ agarose gel electrophoresis ((Applichem, Germany, GmbH). Gelpilot 100 bp plus ladder (Qiagen, Gmbh, Germany) and Generuler 100 bp ladder (Fermentas, Thermo) was used to determine the fragment sizes. The gel was photographed by a gel documentation system (Alpha Innotech, Biometra) and the data was analyzed through computer software (Shin \& Lee, 2009).

\subsection{Virulence gene characterization of $C$. jejuni isolates}

The biochemically and molecular confirmed $C$. jejuni isolates were characterized for recognition of the $c a d F$ virulence gene by PCR (Konkel et al., 1999) utilizing the primers listed in Table 1. 
Table (1): Primers sequences, target genes, amplicon sizes and cycling conditions of $C$.jejuni.

\begin{tabular}{|c|c|c|c|c|c|c|c|c|}
\hline \multirow{2}{*}{$\begin{array}{l}\text { Target } \\
\text { gene }\end{array}$} & \multirow{2}{*}{$\begin{array}{l}\text { Primers } \\
\text { sequences }\end{array}$} & \multirow{2}{*}{$\begin{array}{l}\text { Amplified } \\
\text { segmen (bp) }\end{array}$} & \multirow{2}{*}{$\begin{array}{l}\text { Primary } \\
\text { denaturation }\end{array}$} & \multicolumn{3}{|c|}{ Amplification (35 cycles) } & \multirow{2}{*}{$\begin{array}{c}\text { Final } \\
\text { extension }\end{array}$} & \multirow[t]{2}{*}{ Reference } \\
\hline & & & & $\begin{array}{l}\text { Secondary } \\
\text { denaturation }\end{array}$ & $\begin{array}{l}\text { Anne } \\
\text { aling }\end{array}$ & $\begin{array}{l}\text { Exten } \\
\text { sion }\end{array}$ & & \\
\hline $\operatorname{map} A$ & $\begin{array}{lr}\text { F } \quad(5 ` & \text { CTA } \\
\text { TTT } & \text { TAT } \\
\text { TTT } & \text { TGA } \\
\text { GTG } & \text { CTT } \\
\text { GTG) } & \\
\text { R (5 } & \text {-GCT } \\
\text { TTA } & \text { TTT } \\
\text { GCC } & \text { ATT } \\
\text { TGT } & \text { TTT } \\
\text { TTA) } & \\
\end{array}$ & 589 & $\begin{array}{l}94^{\circ} \mathrm{C} \\
6 \text { min. }\end{array}$ & $\begin{array}{l}94^{\circ} \mathrm{C} \\
50 \text { sec. }\end{array}$ & $\begin{array}{l}57^{\circ} \mathrm{C} \\
40 \\
\text { sec. }\end{array}$ & $\begin{array}{l}72^{\circ} \mathrm{C} \\
50 \\
\text { sec. }\end{array}$ & $\begin{array}{l}72^{\circ} \mathrm{C} \\
3 \mathrm{~min} .\end{array}$ & $\begin{array}{l}\text { Shin \& } \\
\text { Lee(2009) }\end{array}$ \\
\hline cadF & $\begin{array}{lr}\text { F }(5 ` & \text { TTG } \\
\text { AAG } & \text { GTA } \\
\text { ATT } & \text { TAG } \\
\text { ATA TG) } \\
\text { R (5 }{ }^{\circ} \text {-CTA } \\
\text { ATA } & \text { CCT } \\
\text { AAA GTT } \\
\text { GAA AC) }\end{array}$ & 400 & $\begin{array}{l}94^{\circ} \mathrm{C} \\
5 \text { min. }\end{array}$ & $\begin{array}{l}94^{\circ} \mathrm{C} \\
1 \mathrm{~min} .\end{array}$ & $\begin{array}{l}45^{\circ} \mathrm{C} \\
1 \text { min }\end{array}$ & $\begin{array}{l}72^{\circ} \mathrm{C} \\
1 \mathrm{~min} .\end{array}$ & $\begin{array}{l}72^{\circ} \mathrm{C} \\
5 \mathrm{~min} .\end{array}$ & $\begin{array}{l}\text { Konkel } \\
\text { et al., } \\
\text { (1999) }\end{array}$ \\
\hline
\end{tabular}

5.Antimicrobial susceptibility test of C.jejuni isolate

All C.jejuni Confirmed isolates were screened for antimicrobial susceptibility using the stander agar disc diffusion technique as recommended by Clinical and Laboratory Standards Institutions (CLSI, 2014) for susceptibility to 8 different antibiotic disc: Amoxicillin $(10 \mu \mathrm{g})$, Ampicillin $\quad(10 \mu \mathrm{g}), \quad$ Chloramphenicol $(30 \mu \mathrm{g})$, Erythromycin $(15 \mu \mathrm{g})$, Gentamycin $(10 \mu \mathrm{g}), \quad$ Norfloxacin $\quad(10 \mu \mathrm{g})$, Sulfamethoxazole-trimethoprim $\quad(25 \mu \mathrm{g})$, Streptomycin $(10 \mu \mathrm{g})$. After $48 \mathrm{~h}$ of microaerophilic incubation at $37^{\circ} \mathrm{C}$, the clear zones diameter for individual antimicrobial agents were measured and then translated into Sensitive (S) and Resistant (R) categories.

\section{Experimental study}

\subsection{Experimental animal}

Atotal of 60 infant rabbits at 10 days old and $C$.jejuni pathogen free, were obtained from Rabbit production unit, Faculty of Agriculture, Mansoura University. To ensure the absence of Campylobacter infection, rectal swabs were performed immediately after reception of rabbits and plated on sheep blood agar plates containing cefoperazone, vancomycin, and amphotericin B (CVA agar). Rabbits were housed in cages with pads in the bottom. Food and water were provided at libitum, and were allowed to acclimate for 2 days before experiment.

\subsection{Experimental design and infection}

Rabbits were divided into 3 groups, each group has 20 rabbits. Group1: infected untreated with orogastric inoculation with 1 $\times 10^{9}$ colony-forming units (cfu) of $C$. jejuni that were isolated previously and fully identified from naturally infected calves and contaminated raw milk. Group 2: infected and treated with Norfloxacine within $12 \mathrm{hr}$ PI $(1 \mathrm{~cm} / \mathrm{kg})$. Group3: control group.

\subsection{Clinical signs and postmortem:}

Rabbits were observed daily for signs of diarrhea or death. Rectal swabs for bacterial re-isolation were obtained daily until the end of the 2-week observation period. Complete postmortem examinations were done on infected and control animals.

6.4.Fecal inflammatory markers: Were measured according to Nemelka et al. (2009), a stool sample is collected daily in a clean container provided by the laboratory. This sample should be uncontaminated by urine or water. Occult blood (Hemoccult, Beckman Coulter Kit) designed to evaluate 
stool samples for hidden (occult) blood by measuring the heme (non-protein) part of hemoglobin from blood in the stool .Lactoferrin (Leuko-Test), is a glycoprotein present in activated neutrophils when the intestines are inflamed and are shed in stool. Gross blood was detected in stool by nacked eye.

\subsection{Histopathological examination:}

Three rabbits from each group were sacrificed each $12 \mathrm{hr}$ post infection until five days, then once each $24 \mathrm{hr}$ till the end of experiment. The intestines were removed immediately. Specimens were placed in formalin $10 \%$. Representative sections were taken from each specimen and stained with hematoxylin and eosin (Bancroft et al., 2013).

\section{6. immunohistochemical staining for $C$. jejuni}

Sections were permeabilized with $0.1 \%$ Triton X-100 for 15 min, treated with $3.3 \%$ $\mathrm{H} 2 \mathrm{O} 2$ for $15 \mathrm{~min}$, and washed. Samples were blocked for 30 min with $5 \%$ bovine serum albumin and incubated for $1 \mathrm{~h}$ with an in-house mouse polyclonal antiserum against $C$. jejuni or without serum as a control. Samples were then incubated with horseradish peroxidase-conjugated goat anti-mouse $\operatorname{IgG}$ (1:5000; Sigma) for $1 \mathrm{~h}$, developed with 3-amino-9-ethylcarbazole, counterstained with hematoxylin, and mounted with aqueous mounting medium (Shang et al., 2016).

\subsection{Ultra structural examination of intestine:}

For electronmicroscopy, fragments of duodenum, ileum and colon were removed and fixed for $24 \mathrm{~h}$ at $4^{\circ} \mathrm{C}$ in callidine buffer containing glutaraldehyde $2.5 \%$. Samples were then washed in buffer, fixed for $1 \mathrm{~h}$ in osmium tetroxide 1\%, dehydrated, embedded in Epon (Merck), and cut with an ultramicrotome. Semi-thin sections were stained with toluidin blue; ultrathin sections were contrasted with uranyl acetate and lead citrate, before examination with a Philips EM300 electronmicroscope (Electron Microscopy Unit, Mansoura University).

\section{RESULTS}

1.Campylobacter isolation and bacteriological identification

From the total of 140 collected samples, 41 campylobacter strains were isolated as following: 32 out of 100 (32\%) calve fecal samples and 9 out of $40(22.5 \%)$ raw milk samples from the same farms, by cultural methods. Campylobacter. spp. appear as grey color spreading colonies on blood agar media after incubation for $48 \mathrm{hrs}$ at $37 \mathrm{c}$ in microaerophilic condition $\left(10 \% \quad \mathrm{CO}_{2}, 5 \%\right.$ $\mathrm{O}_{2}$ and $58 \% \quad \mathrm{~N}_{2}$ ). Gram staining examination showed pink color spiral rods were arranged as a single or in pairs under microscope $(100 x)$. All isolated strains of Campylobacter spp were then subjected to biochemical tests, which were positive hippurate hydrolysis, catalase test and indoxyl acetate hydrolysis.

\section{Molecular Identification of Campylobacter jejuni isolates}

Seven representative biochemically validated Campylobacter isolates were further molecularly identified through the amplification of map $A$ gene specific to C.jejuni. All isolates recorded the specific product for C.jejuni (589 bp), as shown in fig. 1 . 


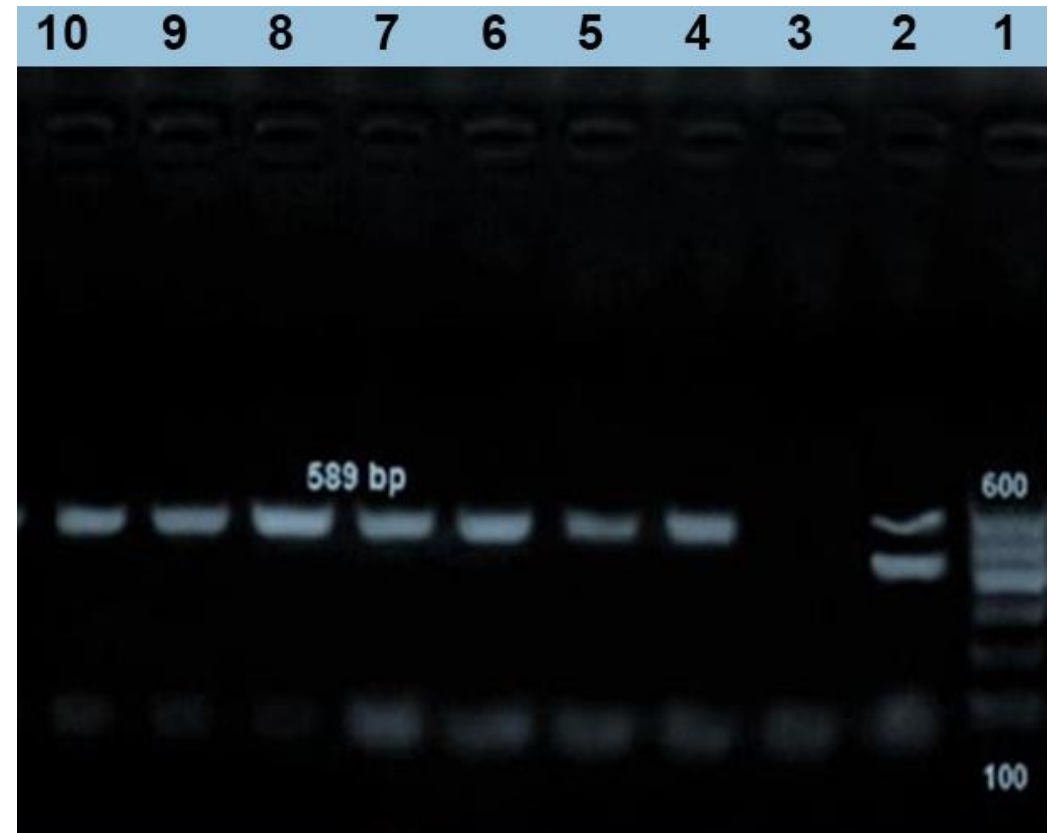

Figure 1: Amplification of the mapA gene of $C$. jejuni isolates. Lane 1: DNA ladder (100 bp.), lane 2: positive control, lane 3: negative control; lanes 4-10: positive $C$. jejuni isolates showing specific bands at $589 \mathrm{bp}$.

The virulence characterization of molecularly identified C.jejuni isolates revealed that eight $(15.22 \%)$ carried the virulence cadF gene among $46 \mathrm{C}$. jejuni isolates and produced the expected product (400), figure 2 .

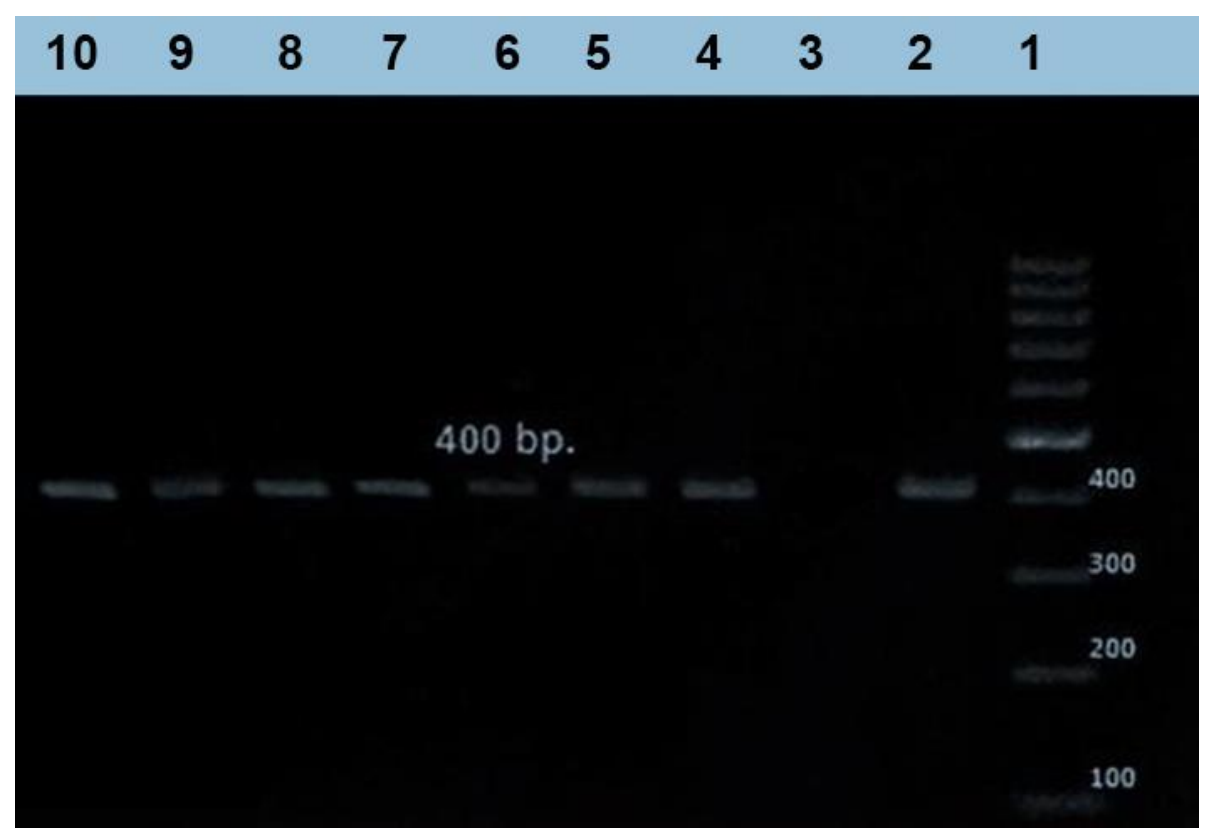

Figure 2: Agarose gel electrophoresis of $C a d F$ gene PCR products in $C$. jejuni isolates: Lane 1: DNA ladder (100 bp), lanes 2: positive control, Lane 3: negative control, Lanes 4 -10: positive $C$. jejuni $\mathrm{CadF}$ gene showing specific bands at $400 \mathrm{bp}$.

\section{Antibiogram profile of isolated $C$.jejuni}

The antimicrobial susceptibility test of molecularly identified C.jejuni isolates (7) were screened against 8 antibiotics. All strains were susceptible to Norfloxacine, Erythromycin,

SulfamethoxazoleTrimethoprime, and Gentamycin. However, isolates showed resistance to Ampicillin, and Amoxicillin, Table 2. 
Table 2: Antimicrobial susceptibility pattern of C.ejuni isolates identified by disc diffusion method.

\begin{tabular}{llll}
\hline \multirow{2}{*}{ Type of antibiotics } & \multicolumn{3}{c}{ Interpretations } \\
\cline { 2 - 4 } & Susceptability (\%) & Intermediate (\%) & Resistant (\%) \\
\hline Ampicillin $(10 \mu \mathrm{g})$ & $0(0 \%)$ & $1(14.3)$ & $6(85)$ \\
\hline Amoxicillin $(10 \mu \mathrm{g})$ & $1(14.3)$ & $2(28.6)$ & $4(57.1)$ \\
\hline S.Trimethoprim $(25 \mu \mathrm{g})$ & $2(28.6)$ & $1(14.3)$ & $4(57.1)$ \\
\hline Erythromycin $(15 \mu \mathrm{g})$ & $5(71.4)$ & $1(14.3)$ & $1(14.3)$ \\
\hline Gentamycin $(10 \mu \mathrm{g})$ & $4(57.1)$ & $1(14.3)$ & $2(28.6)$ \\
\hline Norfloxacin $(10 \mu \mathrm{g})$ & $6(85)$ & - & $1(14.3)$ \\
\hline Chloramphenicol $(30 \mu \mathrm{g})$ & $4(57.1)$ & $1(14.3)$ & $2(28.6)$ \\
\hline Streptomycin $(10 \mu \mathrm{g})$ & $2(28.6)$ & $2(28.6)$ & $3(42.9)$ \\
\hline
\end{tabular}

4.Experimental study:

\subsection{Clinical signs after orogastric} inoculation of $C$. jejuni into rabbits:

After oral challenge with $10^{9} \mathrm{CFU}$ of $C$. jejuni, all $20(100 \%)$ infected untreated rabbits $(\mathrm{G} 1)$ were infected, and exhibited diarrhea after $12 \mathrm{hr}$ post infection which characterized by release of loose, gelatinous unformed bloody stools followed by severe yellow diarrheal fluid. Duration of diarrhea varied between 1 to 4 days, and spontaneously remitted by day 6 after inoculation. None of the rabbits died but subsequently lost weight, off food and became very weak and lethargic. In contrast, in infected-treated group (Gr2), 4 of $20(20 \%)$ of rabbits exhibited mild manifestation in the form of yellow watery diarrhea after $12 \mathrm{hr}$ post infection but did not develope to severe illness and completly recovered after $48 \mathrm{hr}$. In control group (Gr3), appeared normal and did not exhibit any signs of illness, the change in their fecal consistency was not noted throughout the experiment.

\subsection{Fecal inflammatory markers}

Lactoferrin, gross blood and occult blood were measured in feces to investigate the degree of inflammatory response to $C$. jejuni infection in each group as showed in table (3).

Table 3: Fecal inflammatory response of $C$. jejuni experimental infected rabbits.

\begin{tabular}{lclll}
\hline Groups & Days & \multicolumn{3}{l}{ Fecal inflammatory marker [no. positive/no. tested (\%)] } \\
\cline { 3 - 5 } & & Gross blood & Occult blood & Lactoferrin \\
\hline Infected & 1 & $12 / 20(60 \%)$ & $9 / 20(45 \%)$ & $10 / 20(50 \%)$ \\
untreated & 2 & $10 / 20(50 \%)$ & $8 / 20(40 \%)$ & $9 / 20(60 \%)$ \\
& 3 & $7 / 20(35 \%)$ & $7 / 20(35 \%)$ & $8 / 20(40 \%)$ \\
\hline Infected & 1 & $3 / 20(15 \%)$ & $3 / 20(15 \%)$ & $5 / 20(25 \%)$ \\
treated & 2 & $0 / 20$ & $1 / 20(5 \%)$ & $2 / 20(10 \%)$ \\
& 3 & $0 / 20$ & $0 / 20$ & $0 / 20$ \\
\hline control & Any day & All fecal inflammatory markers were negative $(0 / 20)$ \\
\hline
\end{tabular}

All markers were negative on days 6 and 7 in the collected sample stool.

All infected untreated rabbits that developed diarrhea $(100 \%)$ showed gross blood in their stool, this value gradually declined to $35 \%$ by day 3 , but no gross blood was present beyond day 5 . Whereas the infected treated group revealed gross blood in $(15 \%)$ of animals and disappeared in day 2 of experiment. In control group, all fecal inflammatory markers were negative during the study period. lactoferrin was more sensitive compared with gross and occult blood in detecting inflammation and antimicrobial susceptibility.

\subsection{Gross examination:}

The intestine of most infected untreated rabbits (G1) revealed acute enterocolitis indicated by bloody content, hyperemia, petechial hemorrhage and swollen. Small intestine, ceca and proximal colon were distended and fluid-filled (Fig3. A), compared with infected treated rabbits (G2) which exhibit mild gross lesions and control group that show normal intestine. 

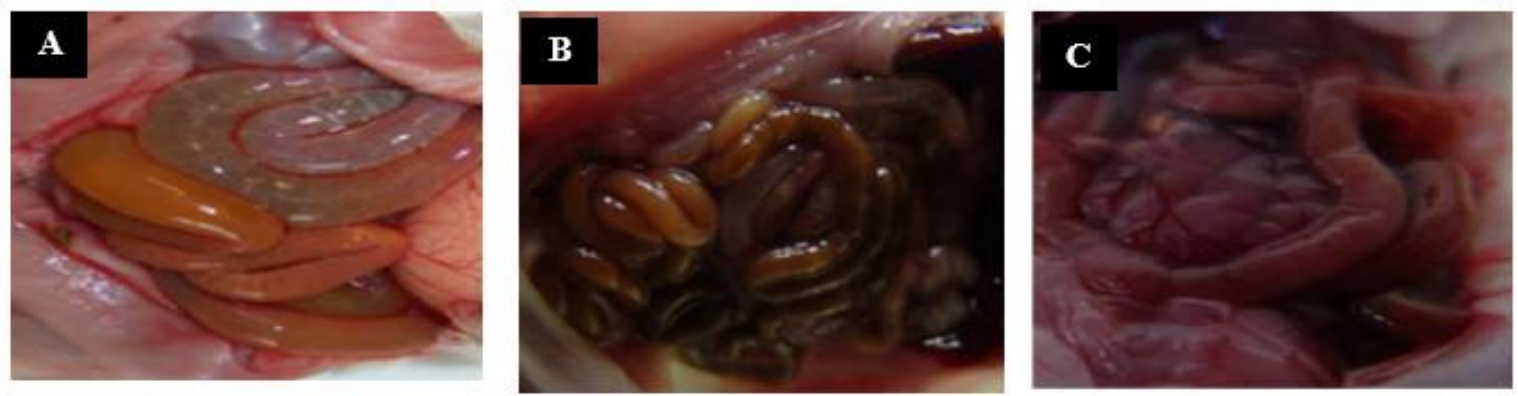

Figure (3): Gross findings in rabbits inoculated with $C$. jejuni isolated from naturally infected calves and cow raw milk. A. The infected untreated rabbits (G1): Showing congested, swollen, distended and fluid-filled intestine. B. infected treated rabbits (G2): Showing mild focal congestion and not distended with fluids. C. Control group (G3): Showing normal intestine.

\subsection{Histopathology:}

The abnormalities of histological analysis of infected rabbits were recorded mainly in the distal small intestine as well as in the colon. Lesions in infected untreated rabbits revealed characteristic progressive changes of the intestinal epithelial morphology. At $12 \mathrm{hr}$ PI, intestinal villi appeared mostly normal with intact lining epithelium (Fig4.A). by $24 \mathrm{hr}$, heterophils were observed in the lamina propria of villi, with small clusters of bacteria were attached and associated with erosions in the epithelial surface (Fig4.B). However most of the lining epithelial layer remained intact except little debris was observed in the lumen. Untill that point there was no evident of extensive disruption and disintegration of villus epithelium. By $36 \mathrm{hr}$ PI, we assessed gradual histopathological changes: the erosions were more pronounced, causing cavities in the epithelial surface and resulting in loss of the actin ring that encircles and protect the villus, epithelial cells became extruding and unprotected which enhance epithelial hyperplasia, at that time luminal depris as well as heterophils and bacteria became more abundant in the lumen and lamina propria $($ Fig4,C). But by $48 \mathrm{hr}$ till $72 \mathrm{hr}$ PI there was widespread damaged, degenerated, and sloughed intestinal mucosa, marked congestion of capillaries in the villi, severe epithelial hyperplasia leading to ulceration, serosal hemorrhage and diffuse polymorphonuclear neutrophilic infiltration (PMN) at the crypt epithelium.
Loss goblet cell and crypt, smucosal ulceration, submucosal congestion and edema were extensive. Moreover, the inflammation extended from the submucosa to the muscle layer (Fig4.D). By the day 5 PI, the severity of intestinal lesions decreased and the damaged epithelial cells from the villus is balanced by proliferation in the crypts (Fig4.E) by day 7 PI, villus epithelial coverage was nearly normal and absence of any significant changes (Fig4.F).

The infected treated group (Fig 5), approximately $20 \%$ of rabbits developed clinical symptoms of $C$. jejuni. By $24 \mathrm{hr}$ PI, the intestinal villi and epithelial coverage were normal with normal mucosa, submucosa and muscularis (Fig5.A). By 36hr PI, exhibited rather mild histopathological changes such as focal damage of epithelial lining villi associated with small clusters of bacteria and heterophilic aggregation in the lamina properia (Fig5.B). By 48hr PI, congestion, edema in lamina properia, single to mild scattered cell infiltrates in mucosa and lamina propria were recorded, but the lesions did not extend to submucosa and muscularis, normal goblet cells and crypts (Fig5.C). By day 3PI recovery phase occurred and characterized by regeneration of villus epithelium with absence of congestion and edema (Fig5.D). By day 4PI, complete regeneration of lamina properia of villi with marked increase of villus length and width (Fig5.E). By day 5PI, intestine showed conical shaped villi 
lining with simple columnar epithelium, with marked increase of villus width and length, normal cryptal glands and goblet cells were seen (Fig5.F).
The comparative histopathological evaluation between infected, infected treated and control groups were illustrated in table (4).

Table 4: Comparision of histopathological findings in all experimental groups:

\begin{tabular}{llll}
\hline Histopathological changes & Experimental groups & & \\
\cline { 2 - 4 } & Infected untreated & Infected treated & control \\
\hline Mucosal ulceration & extensive-diffuse & mild-focal & - \\
mucosal congestion & prominent & minimal & - \\
submucosal congestion & prominent & - & - \\
submucosal, edema & prominent & - & - \\
Inflammation progress & Mucosa/submucosa/muscle & Mucosa & - \\
Muscle edema & prominent & - & - \\
Bacterial Invasion (immunohisto) & Up to muscle layer & mucosa & - \\
\hline
\end{tabular}

卌
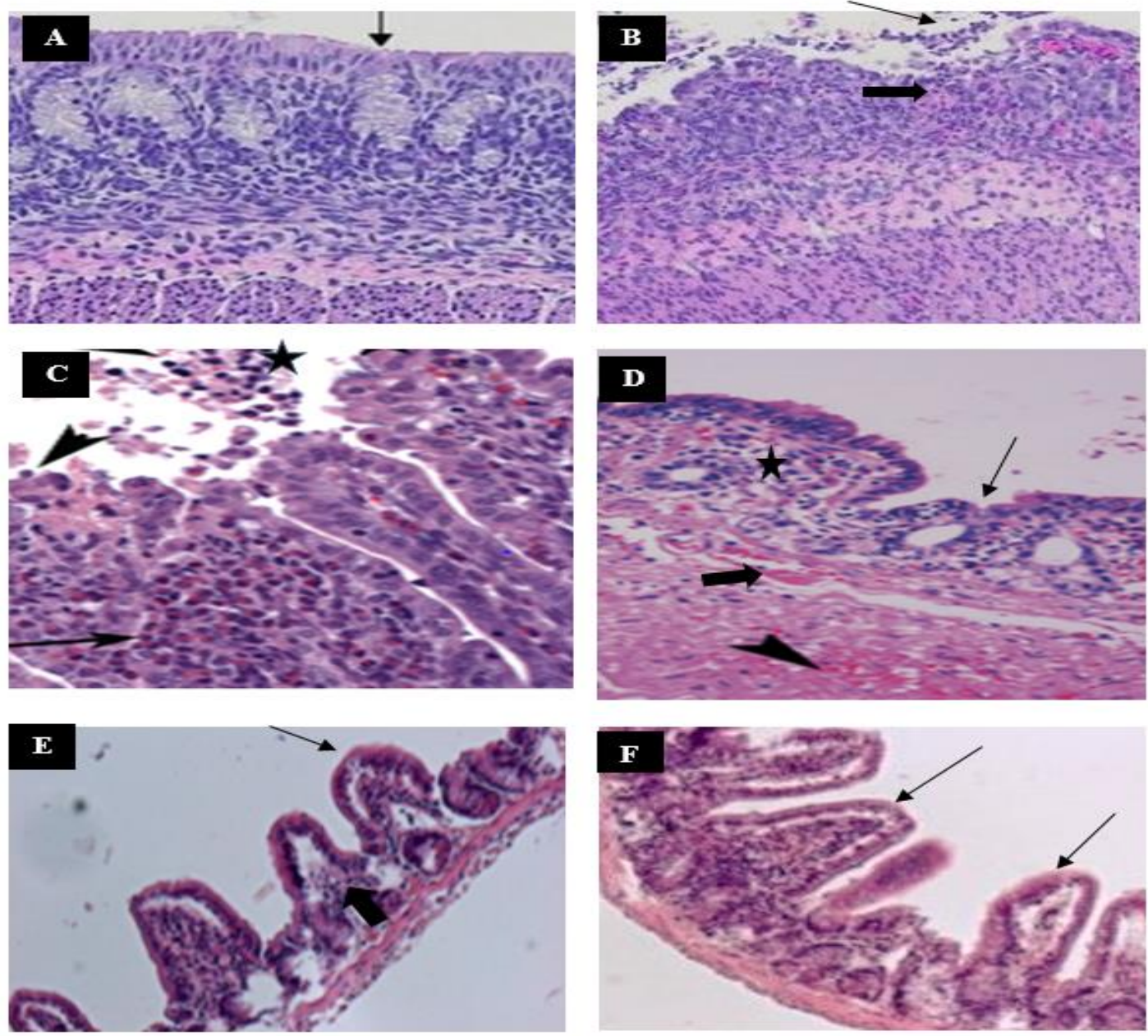

Figure 4: Histopathological changes in the distal small intestine of rabbits infected with $C_{\text {.jejuni isolated }}$ from naturally infected calves and raw milk. A: by $12 \mathrm{hr}$ PI, intestinal surface appear normal and smooth with intact villi and lining epithelium, normal mucosa and submucosa (arrow), H\&E, x20. B: by 24hr PI, erosion of epithelial surface associated with bacterial clusters (thin arrow) and mild heterophilic aggregation in the lamina propria (thick arrow), H\&E, x20. C: by 36hr PI, sloughed or desquamated villus epithelium associated with heterophilic aggregation (star), attached bacteria (arrow head), heterophilic aggregation in the lamina properia (thin arrow), H\&E, ${ }_{440}$. D: by $48 \mathrm{hr}$ PI, degeneration and sloughing of villus epithelium (thin arrow). Congestion of blood vessels and infiltration with PMN in the lamina propria (star), submucosal congestion and edema (thick arrow), Congestion and edema in the muscularis externae (arrow head), H\&E, x40. E: by the day 5 PI, regeneration of the damaged villus epithelium (thin arrow), by proliferation in the crypts (thick arrow). F: by day 7 epithelial coverage appear nearly normal with marked increase in length and width of villi (arrow), H\&E, $x_{100}$. 

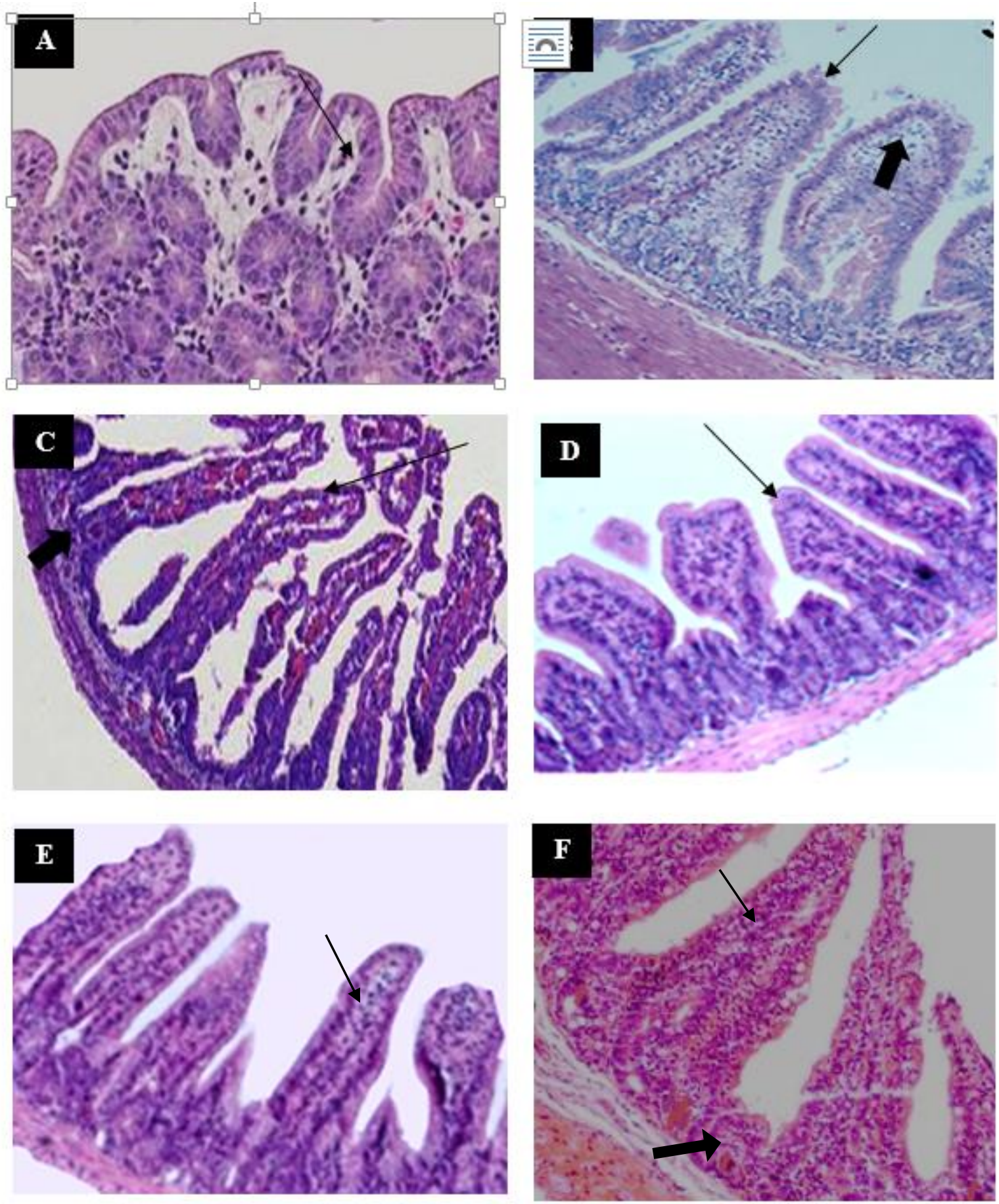

Figure 5: Histopathological changes in the distal small intestine of rabbits infected with C.jejuni isolated from naturally infected calves and raw milk and treated with Norfloxacine. A: by $12 \mathrm{hr}$ PI, normal intestinal villi with intact epithelial coverage (arrow) H\&E, x10. B: by 24hr PI, focal damage of epithelial lining villi (thin arrow), associated with small clusters of bacteria and heterophilic aggregation in the lamina properia (thick arrow) H\&E, x40. C: by 48hr PI, mild congestion, edema and single scattered cell infiltrates in lamina propria (thin arrow), normal submucosa and muscularis, normal goblet cells and crypts (thick arrow) H\&E, x40. D: by day 3PI, regeneration of villus epithelium and absence of congestion and edema (arrow) H\&E, x40. E: by day4, normal lamina properia of villi with marked increase in length (arrow), H\&E, x40. F: by day 5PI, showing conical shaped villi lining with simple columnar epithelium (thin arrow), with marked increase of villus width and length, normal cryptal glands and goblet cells (thick arrow) H\&E, x40. 


\subsection{Immunohistochemistry:}

The intestinal tissue sections from all groups were immunostained with $C$. jejuni antibody. By $24 \mathrm{hr}$ PI, In the infected rabbits (G1\& G2), C. jejuni antigen were detected through the lumen of the small and large intestines as well as between enterocytes, or intestinal absorptive cells, are simple columnar epithelial cells which line the inner surface of the small and large intestines (fig.6A). But, by $48 \mathrm{hr}$ PI, the infected untreated group (G1), immunoperoxidase labeling was intense in the mucosal region and this intense labeling extended into the submucosa and muscularis as well as the paracellular junction and at the basolateral surface of the epithelium. (Fig. 6B). However, by 48hr PI in the infected treated group (G2), immunostained sections showed immunoperoxidase labeling in the mucosa only and not extended to ather layers of intestine (fig.6C). The tissue sections of negative control group showed no immunoperoxidase labeling was seen (fig.6D).
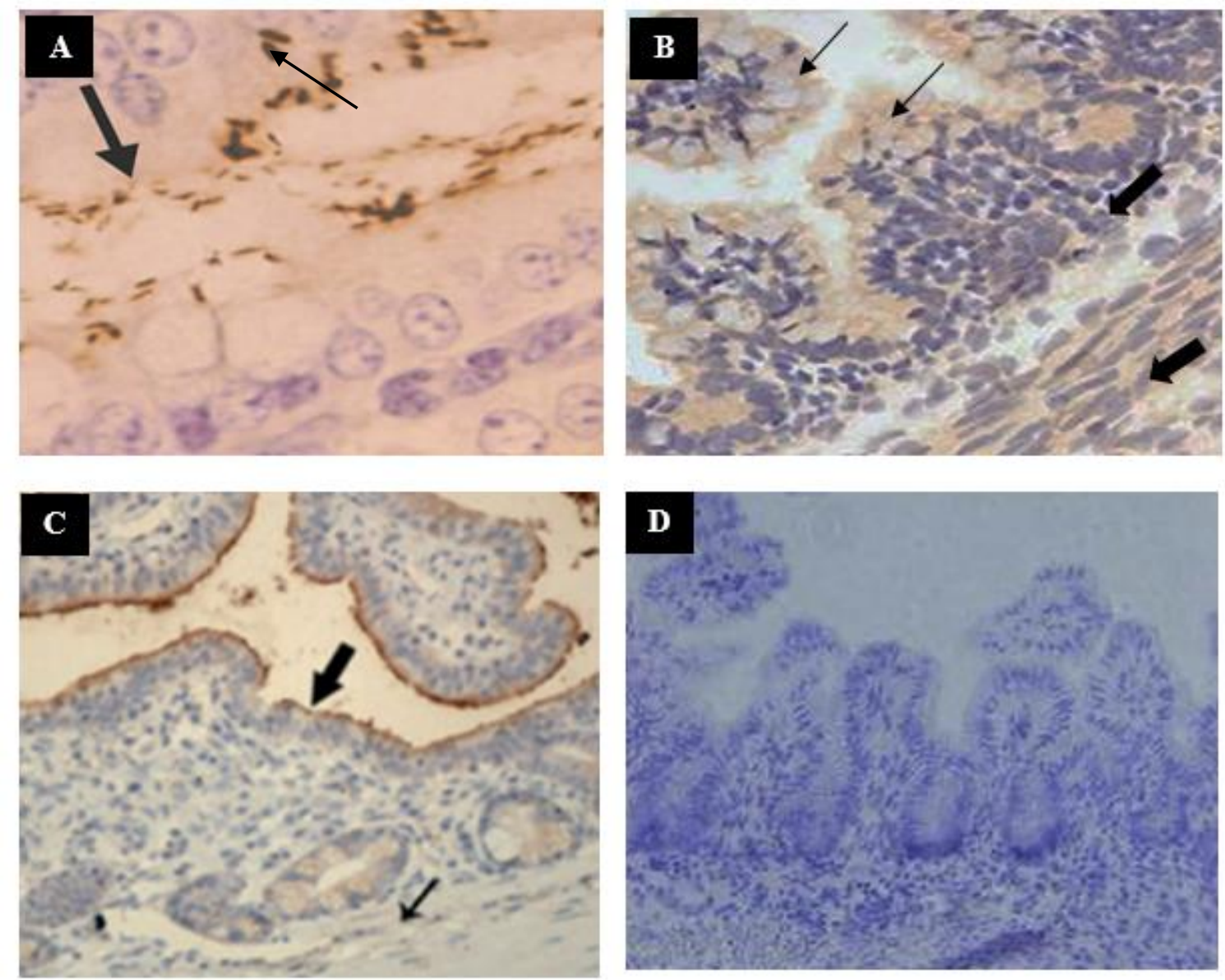

Figure 6: Immunohistopathological staining of rabbit intestinal tissue sections infected

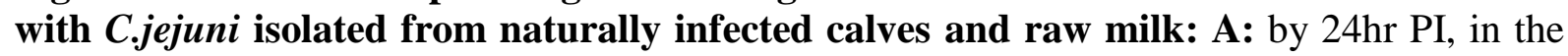
infected rabbits (G1\&G2) showing presence of C.jejuni through the luminal surface of intestine (thick arrow) as well as between enterocytes which lining the inner surface of villi (thin arrow). X40. B: by $48 \mathrm{hr}$ PI, in the infected untreated rabbits showing diffuse brown immunoperoxidase reaction in the cell surface and mucosa (thin arrow) $\mathrm{x} 40$. The reaction extended to the submucosa and muscularis (thick arrow). C: by $48 \mathrm{hr}$ PI in the infected treated treated rabbits showed a significant immunoperoxidase reaction on the cell surface (thick arrow), and also labeling within the mucosa (thin arrow), but not extended to submucosa and muscularis. D: no positive brown staining reaction are seen in negative control rabbits. 


\subsubsection{Ultrastructural changes in intestinal epithelial cells induced by C.jejuni in rabbits:}

Transmission electron microscopy (EM) was used to further study how $C$. jejuni interacts with host epithelial cells of small intestine post infection. Transmission EM showed that $C$. jejuni did not induce any structural changes in the epithelium during the first $12 \mathrm{~h}$ post infection. Moreover $C$. jejuni was not observed by EM in the lumen, tight junctions, desmosomes, or villus brush border, which remained intact in all experimental groups (Fig. 7A). By 24hr PI, numerous clusters of bacteria were observed in the lumen and closely attached to the villus tips causing partial destruction of the brush border while the adjacent epithelium without bacteria appeared normal (fig.7B). By 36hr PI, intraepithelial lymphocytic infiltration were stimulated, cellular swelling and edema were also observed with cavities at the sight of attachment for invasion (Fig. 7C). By 48hr PI, the cellular membrane next to bacteria was invaginated, followed by diffuse disorganization of the epithelium architecture, and degeneration in the untreated group (fig.7D). By 60hr PI and after invasion, bacteria were surrounded by enterocyte vacules in which most of them lysed in the treated group. While in the untreated group retained their shape and size (fig.7E). By $72 \mathrm{hr} \mathrm{PI}$, the bacterial invasion fllowed by severe intracellular lymphocytic infiltration and cell swelling in the untreated group (fig.7F).
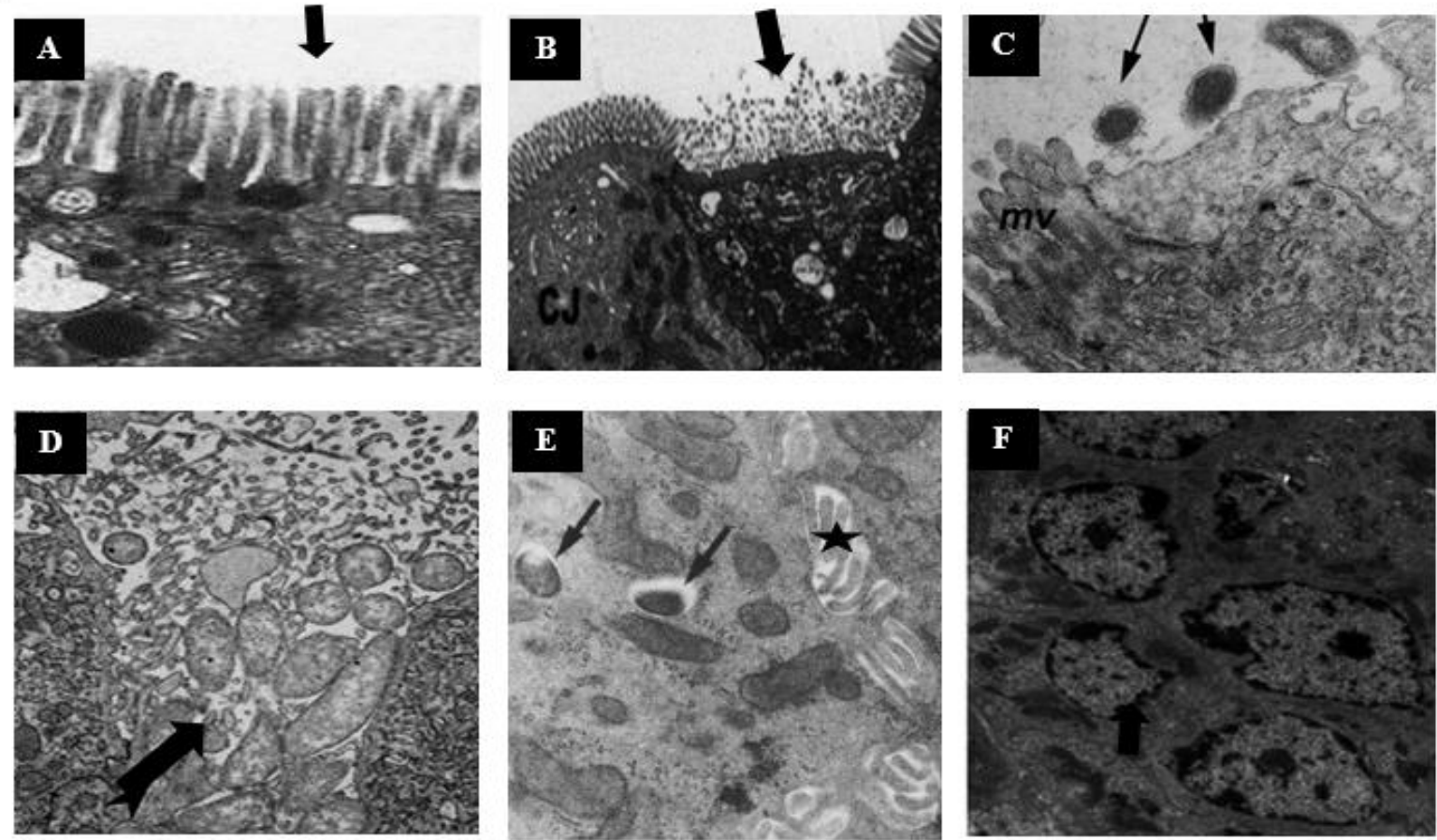

Figure 7: Transmission electron microscopy of the distal small intestine of rabbits inoculated with $\boldsymbol{C}$. jejuni. A: by $12 \mathrm{hr}$ PI, $C$. jejuni are not observed in lumen and brush border remain intact with tight junction between villi (arrow), X54,000. B: by 24hr PI, clusters bacteria attached to the epithelial cell surface and associated with loss of microvilli at the site of attachment (arrow), while the adjacent epithelium without bacteria appeared normal and intact (thick arrow), X35,000. C. By 36hr PI, C. jejuni closely attached to epithelial surface causing cavities for invasion (arrow), X 54,000 .D: by 48hr PI, C.jejuni accumulated in the cavities of invasion below the normal level of adjacent intact epithelium (arrow), $\mathrm{X}$ 54,000. E: by $60 \mathrm{hr}$ PI, intracellular C.jejuni apparently free in the cytoplasm were surrounded by enterocyte vacules (arrow). mitochondria (star). X 35,000. F: by $72 \mathrm{hr}$ PI, bacterial invasion Followed bycell swelling, edema and severe inflammatory infiltrate of intraepithelial lymphocytes, (arrow), X 65,000. 


\section{DISCUSSION}

The main goal of this work was to determine the virulence of $C$. jejuni and the post infection pathogenesis as well as antimicrobial resistance as part of the characterization of this strain for future treatment planning and efficacy studies.

C. jejuni is generally considered commensals of livestock and did not normally cause clinical disease in adult animals, but now has emerged as one of the most common causes of serious foodborn zoonotic diseases worldwide for both human and animal and is responsible for gastroenteritis in young livestock in many industrial countries (Kaakoush et al., 2015). In the current study, Cultural examination, staining characteristics, biochemical tests and finally PCR were performed for the characterization of the Campylobacter spp. and the colony characteristics were exhibited grey color which was supported by Kabir et al. (2015) and Mehedul et al. (2018). The routine isolation and identification of Campylobacter spp. in laboratories were conducted on the basis of cultural and biochemical methods which was supported by Jamshidi et al. (2008). Hippurate hydrolysis test was used for discriminating between $C$. jejuni and $C$. coli which was also used by several researchers (Kabir et al., 2014 and Shiramaru et al., 2012). The current study recorded 32 (32\%) and $9(22.5 \%)$ Campylobacter spp. from 100 fecal and 40 raw milk samples respectively during the study period. The PCR is adefinitive, reliable, easy method and is required to facilitate rapid identification for $C$.jejuni (El-Kholy et al., 2016). In the current study, seven C.jejuni isolates that were biochemically identified were further molecularly characterized by mapA gene amplification specific to C.jejuni, all the isolates demonstrated positive specific product $(589 \mathrm{bp})$ for C.jejuni which is supported by Ghoneim et al. (2020). With respection to the virulence properties of $C$.jejuni, all the seven isolates carried virulence campylobacter adhesion fibronectin (the $c a d \mathrm{~F}$ ) and generated the expected product (400bp), which agree with Elsayed et al. (2019) who reported that $c a d \mathrm{~F}$ is the most virulent gene campylobacter adhesion.

Antimicrobial susceptibility test represents one of the most important tasks of the clinical microbiology laboratory especially in veterinary medicine, because of the interrelation between resistance found in strains of animal origin and humans. Also it can be used as an epidemiological tool and for the definition of the proper treatment of infections, consequently preventing or creating strategies that minimize the dissemination of resistant bacterial strains, mainly multiresistant ones of $C$. jejuni (Hagos et al., 2021) which is emerged by WHO as aproblem of puplic health importance (Heredia and Garcia, 2018).

In the current study, 7 C.jejuni isolates were investigated for their antimicrobial sensitivity pattern. The percentage of ampicillin and amoxicillin resistant $C$.jejuni isolates were $85 \%$ and $57 \%$, respectively, and highest susceptibility percent with norfloxacine and erythromycin $85 \%$ and $71.4 \%$ respectively even with multidrug resistance isolates. This was in agreement with Faris (2015) who reported $97.2 \%$ and $83.3 \%$ for ampicillin and amoxicillin, respectively. Moreover, Macrolides and Fluoroquinolones are usually the drug of choice for treatment $C$.jejuni isolates.

In the current study, we developed a simple rabbits model of campylobacteriosis induced intestinal pathology and diarrhea. This experimental model enabled us to define several key features of the pathogenesis. Rabbits developed diarrhea within $48 \mathrm{~h}$ after oral inoculation of live $C$. jejuni contained mucus and gross blood. The clinical signs and pathological lesions produced in the rabbits like those observed in humans and other large-animal models. C. jejuni multiplied in the distal small intestine and cecum of rabbits with large 
populations of $C$. jejuni, indicating its possible role in the pathogenesis of campylobacteriosis (Shang et al., 2016). Although diarrhea resolved spontaneously by day 4 post infection, the untreated rabbits may excrete bacteria asymptomatically for as long as $2 \mathrm{wk}$, these results supported by Black et al. (1988); Wassenaar and Blaser (1999). In the current study, the inflammatory nature of the diarrhea was further confirmed by the presence of lactoferrin and occult blood in stools. Compared with occult blood, lactoferrin was more sensitive in detecting inflammation that agreed with Stintzi (2005). Fecal inflammatory markers were highly positive in G1(infected untreated), whereas were mild in G2 (treated), and negative in G3(control). These results agreed with Cook et al. (2020) who reported that fecal biomarkers result reflects the underlying GIT inflammatory conditions, moreover it can be used as amonitor response to intestinal therapy.

In the current study, infected untreated rabbits showed marked disruption of the villous epithelial surface in the small intestine, damage of the brush border was noted in areas adjacent to bacteria that appeared to be bound to the epithelial cells, all appear to contribute to villus disruption and the breakdown of epithelial barrier function, this may be attributed to effacement of microvilli, re-distribution of cytoskeletal and tight junction proteins, and extrusion of epithelial cells in the small intestine as recorded by Nemelka et al. (2009). Our histopathological finding revealed that microbial activities occurring mainly at the intestinal level and more significant than extraintestinal invasion as no histologic changes were seen in livers, kidneys, lungs, or mesenteric lymph nodes, that agreed with Shang et al. (2016) who reported that peritoneal histopathologic evaluation revealed no significant changes in infected animals at anytime during the study.
In the current study, based on immunohistochemical staining, we suggested that C.jejuni is capable of invading intestinal tissues. In the infected untreated rabbits, stained bacterial cells were observed in deep tissues as well as the paracellular junction of the epithelium and extended to muscularis compared to treated group which observed in lamina properia and mucosae only, similarly with Nemelka et al. (2009) who reported the immunohistochemical stained $C$. jejuni (brown stain) can be seen in deep tissues of infected rabbit.

In the current study, for further understanding how $C$. jejuni interacts with host epithelial cells, we visualized the epithelium in the small intestine of infected rabbits by electron microscopy (EM), which revealed that adherence would be the first step of invasiveness as $C$. jejuni did not induce any structural changes in the epithelium during the first $12 \mathrm{~h}$ after infection and $C$. jejuni was not observed in the lumen, tight junctions which remained intact. However, clusters of attached bacteria were observed $24 \mathrm{~h}$ postinfection, particularly near the villus tips. Partial destruction of the brush border, infiltration of intraepithelial lymphocytes, and intercellular swelling were observed at $63 \mathrm{hr}$ PI. the epithelium was disorganized, and necrotic with severe infiltration of intraepithelial lymphocytes was observed at $72 \mathrm{hr}$ PI, this results agree with Shang et al. (2016).

\section{CONCLUSION}

The implementation of hyagenic practices during milking and proper handling of milk during calves feeding, regular monitoring of antibiogram profile are very crucial in preventing $C$.jejuni infection, colonization and intestinal damage and subsequently economic loss in dairy farm. suggesting that experimental models may be useful to study the mechanisms and the pathogenesis of $C$. jejuni-induced intestinal disease. 


\section{REFERENCES}

Achá, S.J.; Kühn, I.; Jonsson, P.; Mbazima, G.; Katouli, M. and Möllby, R. (2004): Studies on Calf Diarrhea in Mozambique: Prevalence of Bacterial Pathogens. Acta Vet. Scand. 45:27-36.

Andrzejewska, M.; Szczepańska, B.; Śpica, D. and Klawe, J.J. (2015): Trends in the occurrence and characteristics of Campylobacter jejuni and Campylobacter coli isolates from poultry meat in Northern Poland. Food Control, 51, 190-194.

Bancroft, J.D.; Layton, C. and Suvarna, K. (2013): Bancroft's Theory and Practise of Histological Techniques (7th edition), Publisher: Elsevier ISBN: 978-0-7020-4226-3.

Bartels, C.J.; Holzhaue,r M.; Jorritsma, R.; Swart, W.A. and Lam, T.J. (2010): Prevalence prediction and risk factors of enteropathogens in normal and non normal faces of young Dutch dairy calves. Prev. Vet. Med.93:162-169.

Black, R.E.; Levine, M.M.; Clements, M.L.; Hughes, T.P. and Blaser, M.J. (1988): Experimental Campylobacter jejuni infection in humans. J Infect Dis 157:472-479.

Cho, Y. (2012): Ecology of calf diarrhea in cow-calf operations. Iowa State University Graduate theses and dissertation paper pp. 126-142.

CLSI (Clinical and Laboratory Standards Institute). (2014): Performance standered for antibiotic suceptability testing; twenty fourth informational supplement. CLSI document M100$\mathrm{S} 24$.

Cooke, A.S.; Watt, K.A.; Albery, G.F.; Morgan, E.R. and Dungait, J.A.J. (2020): Lactoferrin quantification in cattle faeces by ELISA. PeerJ 8:e8631.

El-Kholy, M.A.; Meshref, M.S.; El-Gedawy, A.A. and Esam, R.M. (2016): Prevalence of Campylobacter species in milk and some dairy products JOURNAL OF VETERINARY MEDICAL RESEARCH 23 (2): 133 142.

Elmali, M. and Can, H.Y. (2019): Antimicrobial susceptibility and virulence-associated genes in Campylobacter isolates from milk and wastewater in Hatay, Turkey. Ciência Rural, 49(5), 1-8.

Elsayed, M.; Tarabees, R.; Shehata, A.; Harb, $O$. and Sabry, A. (2019): Virulence repertoire and antimicrobial resistance of Campylobacter jejuni and Campylobacter coli isolated from some poultry farms in Menoufia governorate, Egypt. Pakistan Veterinary Journal, 39(2), 261-265.

Faris, G. (2015): Identification of Campylobacter spp. and their Antibiotic resistance pattern from raw bovine meat in Addis Ababa, Ethiopia. IJMIR. 4(1):001-5.

Foster, G.; Holmes, B. and Steigerwal,t A.G. (2004): Campylobacter insulaenigrae sp.nov., isolated from marine mammals.Int J Syst Evol Microbiol 2004;54:2369-73.

Ghoneim, H.N.; ABDEL-MOEIN, A.K.; BARAKA, A.M.A.; HEGAZI, G.A. and $A B D E L-R A Z I K, A . K$. (2020): Isolation and molecular characterization of Campylobacter jejuni from chicken and human stool samples in Egypt. Food Science and Technology, ISSN 01012061.

Hagos, Y.; Gugsa, G.; Awo, L.N.; Ahmed, M.; Tsegaye, Y. and Abebe, N. (2021): Isolation, identification, and antimicrobial susceptibility pattern of Campylobacter jejuni and Campylobacter coli from cattle, goat, and chicken meats in Mekelle, Ethiopia. PLoS ONE 16(2): e0246755.

Heimesaat, M.M.; Fischer, A.; Alutis, M.; Grundmann, U.; Boehm, M. and Tegtmeyer, N. (2014): The impact of serine protease HtrA in apoptosis, intestinal immune responses and extraintestinal histopathology during Campylobacter jejuni infection of infant mice. Gut Pathogens 6:16.

Heredia, N. and Garci'a, S. (2018): Animals as sources of food-borne pathogens: A review. Animal Nutr. ; 4:18, 250e255.

Ibrahim, E.D. (2007): Studies on microbial causes of diarrhea in calves. M.V.Sc. Thesis, Fac. Vet. Med., Kafr El-Sheikh Univ.

Jamshidi, A.; Bassami, M.R. and Farkhondeh, T. (2008): Isolation and identification of Campylobacter spp. and Campylobacter coli from poultry 
carcasses by conventional culture method and multiplex PCR in Mashhad, Iran. Iran J Vet Res. 9:132-7.

Kaakoush, N.O.; Castaño-Rodríguez, N.; Mitchell, H.M. and Man, S.M. (2015): Global epidemiology of Campylobacter infection. Clin. Microbiol. Rev., 28:687-720.

Kabir, S.M.L.; Asakura, M. and Shiramaru, S. (2015): Molecular identification and antimicrobial resistance profiles of Campylobacter strains of poultry origin in India with special emphasis on fluoroquinolone resistance. Asian J Med Biol Res;1:1-8.

Kabir, S.M.L.; Sumon, M.H. and Amin, M.M. (2014): Isolation, identification and antimicrobialresistance patterns of Campylobacter Species from broiler meat sold at KR market of Bangladesh Agricultural University campus. J Agric Food Tech; 4:1-7.

Konkel, M.E.; Gray, S.A.; Kim, B.J.; Garvis, S.G. and Yoon, J. (1999): Identification of the enteropathogens Campylobacter jejuni and Campylobacter coli based on the cadF virulence gene and its product, Journal of Clinical Microbiology, 37, 510-517.

Li, L.; Mendis, N.; Trigui, H.; Oliver, J.D. and Faucher, S.P. (2014): The importance of the viable but non-culturable state in human bacterial pathogens. Frontiers in Microbiology, 5, 258.

Mehedul, M.D.I.; Kabir, S.M.L.; Lubna, M.M.; Ziaul Haque, A.K.M.; Neogi, B.S. and Yamasaki, S. (2018): Isolation, molecular identification and antimicrobial resistance patterns of Campylobacter species of dairy origin: First report from Bangladesh, Veterinary Science Development 2018; volume 8:7838.

Meir, R.; Maharat, O.; Farnushi, Y. and Simanov, L. (2010): Development of a real-time TaqMan RT-PCR assay for the detection of infectious bronchitis virus in chickens, and comparison of RT-PCR and virus isolation. J. Virol. Methods. 163:190-194.

Miller, R.S.; Miller, W.G.; Behringer, M.; Hariharan, H.; Matthew, $V$. and Oyarzabal, O.A. (2010): DNA identification and characterization of Campylobacter jejuni and
Campylobacter coli isolated from caecal samples of chickens in Grenada. Journal of Applied Microbiology, 108(3), 1041-1049.

Modi, S.; Brahmbhatt, M.N.; Chatur, Y.A. and Nayak, J.B. (2015): Prevalence of Campylobacter species in milk and milk products, their virulence gene profile and antibiogram, Veterinary. World 8(1): 1-8.

Murray, P.R.; Baron, E.J.; Jorgensen, J.H.; Landry, M.L. and Pfaller, M.A., editors. (2007): Manual of Clinical Microbiology. 9th ed. ASM Press, American Society of Microbiology, Washington, DC.

Nemelka, W.K.; Brown, W.A.; Wallace, M.S.; Jones, E.; Asher, V.L.; Pattarini, D. and Applebee, L. (2009): Immune Response to and Histopathology of Campylobacter jejuni Infection in Ferrets (Mustela putorius furo) Kevin. Comparative medicine, Vol 59, No 4. Pages 363-371.

Prescott, Bueschel, D.M.; Keel, M.K.; Glock, R.D.; Cuneo, P.; DeYoung, D.W.; Reggiardo, C.; Trinh, H.T. and Songer, J.G. (2008): A possible role for Clostridium difficile in the etiology of calf enteritis. Vet. Microbiol. Mar. 18: 127(3-4): 343-352.

Roberts, D. and Greenwood, M. (2003): Isolation and enrichment of microorganisms, In: Practical Food Microbiology, third Ed. D. Blackwell Publishing Ltd., Malden, MA, pp. 131192

Shang, Y.; Ren, F.; Song, Z.; Li, Q.; Zhou, X.; Wang, X.; Xu, Z.; Bao, B.; Wan, T.; Lei, A. and Wang, M. (2016): Insights into Campylobacter jejuni colonization and enteritis using a novel infant rabbit model. Scientific Reports, 6:28737.

Shiramaru, S.; Asakura, M. and Inoue, H.A. (2012): Cytolethal distending toxin genebased multiplex PCR assay for detection of Campylobacter spp. in stool specimens and comparison with culture method. J Vet Med Sci, 74:85762.

Stintzi, A. (2005): Use of genome-wide expression profiling and mutagenesis to study the intestinal lifestyle of Campylobacter jejuni. Infect. Immun. 73, 1797-1810 (2005). 
Uhde, F.L.; Kaufmann, T.; Sager, H.; Aldini, S.Z.; Anoni, R.; Schelling, E. and Meylan, M. (2008): Prevalence of four enteropathogens in the faeces of young diarrhoeic dairy calves in Switzerland. Vet. Rec. Sep. 163 (12): 362:6.

Wassenaar, T.M. and Blaser, M.J. (1999): Pathophysiology of Campylobacter jejuni infections of humans. Microbes Infect 1:1023-1033.

Wilson, D.L.; Rathinam, V.A.; Qi, W.; Wick, L.M.; Landgraf, J.; Bell, J.A.; Plovanich-Jones, A.; Parrish, J.; Finley, R.L.; Mansfield, L.S. and Linz, J.E. (2010): Genetic diversity in Campylobacter jejuni is associated with differential colonization of broiler chickens and C57BL/6J IL10-deficient mice. Microbiology, 156(7): 20462057.

Wudu, T.; Kelay, B.; Mekonnen, H.M. and Tesfu, K. (2008): Calf morbidity and mortality in smallholder dairy farms in Ada'a Liben district of Oromia, Ethiopia. Trop. Anim. Health Prod. 40:369-376.

Younis, G.; Awad, A. and Khairy, M. (2018): Molecular characterization and virulence of Campylobacter jejuni isolated from broiler chickens. International Journal of Poultry Science, 17(10), 499-506.

\section{متلازمة الاسهال التي تسببه الكمبيلوبكتر جيجوناى في العجول هالة محدد اسعاعيل ، شبيرين سامى مصطفى}

Email: ibrahimsabry.gravena@gmail.com Assiut University web-site: www.aun.edu.eg

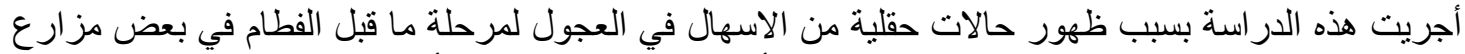
الدقهلية والتي لم تستجيب للعلاج ببعض المضادات الحيوية مما أدى زيادة عدد الحالات وأطالة فترة العلاج وبالتالي خسائ فيائر اقتصادية كبيرة.

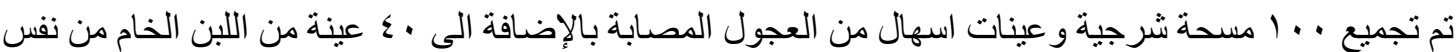

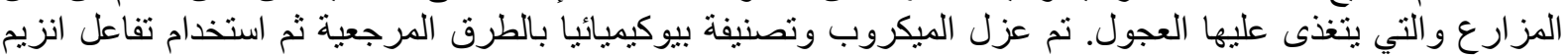

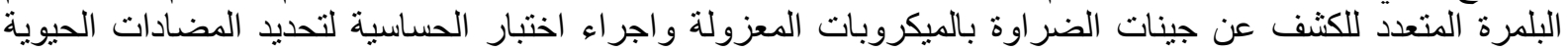

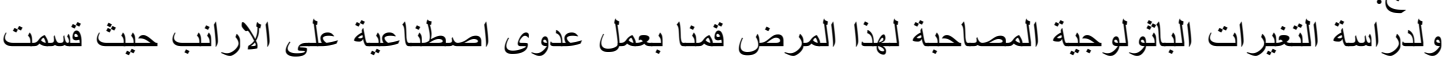

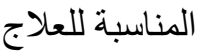

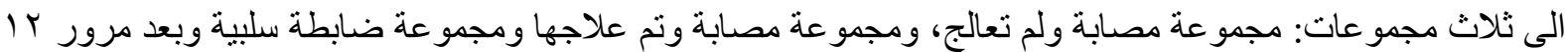

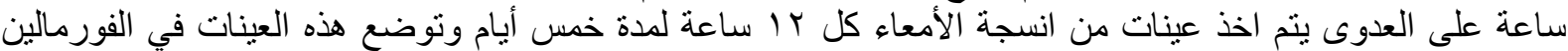

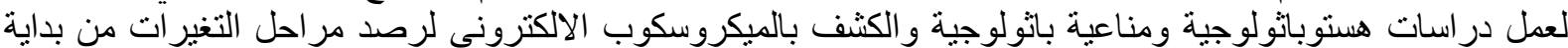
العدوى وحتى توقف الاسهال في المجمو عات التهات الثلاثئة

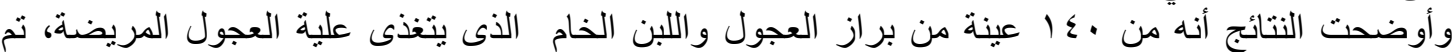

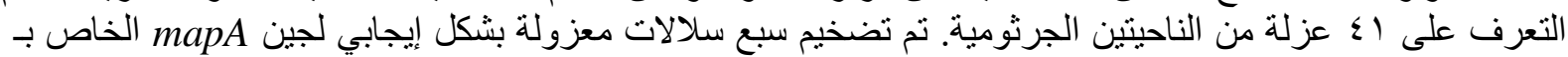

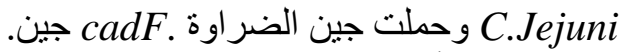
كما أوضحت اختبار الحساسية لهذة المعزوراتلات انها تقاوم الأموكسيسيلين والأمبيسيلين وقابلة للتأثر بشدة

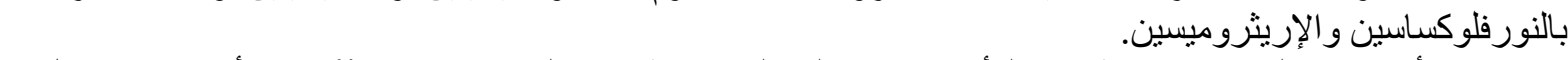

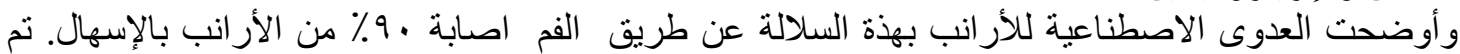

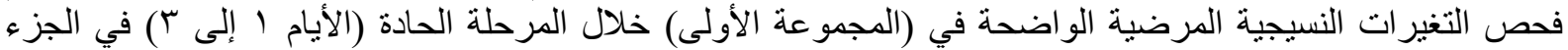

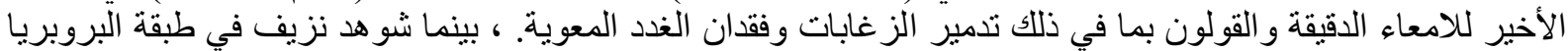

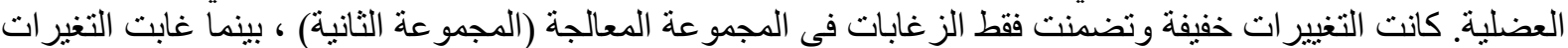

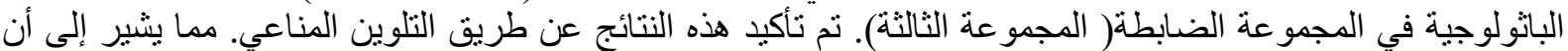

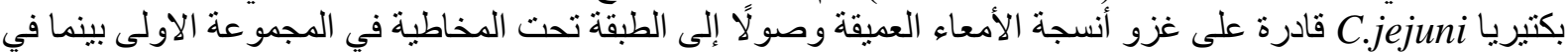

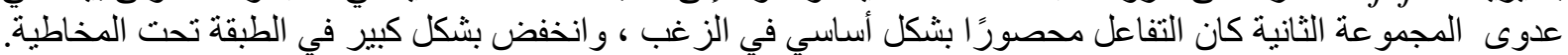

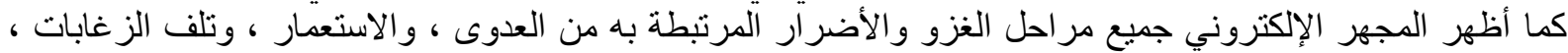

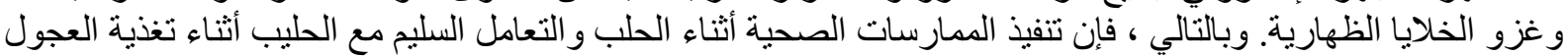

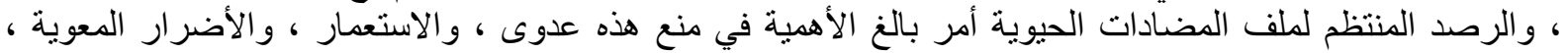
وبالتالي الخسائر الاقتصادية في المزارع الحلابة. 